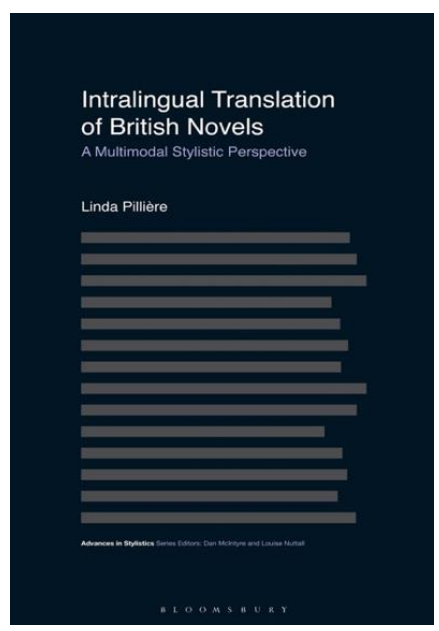

\title{
Pillière, Linda. Intralingual Translation of British Novels. A Multimodal Stylistic Perspective. Bloomsbury Academic, 2021, 270 pages.
}

\author{
Sofía Monzón \\ University of Alberta
}

From the beginning of her book, Intralingual Translation of British Novels. A Multimodal Stylistic Perspective, Linda Pillière catches the attention of her readers. The opening scene is set in a bookshop where you stand with different editions of the same book in your hands and, as you ponder, the revelation occurs: Is this a copy, an adaptation, a new edition? A translation, perhaps? What happened in the editorial process when adapting this book for a geographically different audience? From the differences at the paratextual level (cover, illustrations, typeface, footnotes) to the stylistic choices (lexis, tense, syntax and punctuation), Pillière reminds us that the changes in a text are not irrelevant. Ultimately, there seems to be a reason behind everything in the editorial market, for "[i]f they did not influence the potential buyer, major publishing houses would not spend time and money on reformatting texts. The world of publishing is, let us not forget, first and foremost a commercial enterprise" (24), writes Pillière.

Historically, the discipline of translation-also linguistics prior to it-, has centered almost entirely on interlingual translations, that is, a transfer between different languages. However, Pillière's interest lies in studying intralingual translations, following Jakobson's categories for translation (1959). She declares that the American English (AmE) editions of British English (BrE) novels can be understood as intralingual translations, which are "the rewording or rewriting of a text by means of signs of the same language" (25). By focusing on this type of translation, one that has been greatly 
neglected by translation studies up until the present time, Pillière identifies the gap and devotes Chapter 1 of her book to explaining Jakobson's concepts more in depth, and opens the ground for a very detailed state of the art regarding previous works that have recently touched on this topic.

In order to carry out her ambitious enterprise, she focuses on AmE editions of BrE novels and underlines how this kind of yet peripheral research can help translation studies break down the division started by the formalists in order to find a more enriching way of looking at transfers and adaptations through the lens of stylistics. Previous research, Pillière notes, brought to the forefront lexical changes when comparing English intralingual translations, specifically targeting children's literature, one of the most renowned examples being J. K. Rowling's bestselling Harry Potter series, and its adaptation for the US readership. Nonetheless, seeking to further this line of study, Pillière's corpus of over 80 texts includes "expert-to-lay translation, adaptations of classics for children, and modern renderings of classics" (26). The works chosen by Pillière were published between 1980 and the present day, and her reasoning behind selecting such a period is the many changes that the publishing industry has experienced in the last decades. The corpus is varied in terms of genre, including popular fiction, travelogues, biography, children's fiction, Booker Prize winners, and translations.

Rather than merely comparing the different versions under the light of dialectal, geographical differences, Pillière utilizes the 'cultural turn' in translation studies (Bassnett and Lefevere 1990, 1995), in conjunction with newly explored ideas borrowed from the field of sociology, namely the power relation from which literature and translation cannot escape. Furthermore, Pillière emphasizes the key role that publishers hold in the book industry and their control over literary manuscripts. In this vein, the author draws different conclusions regarding the North American editorial market and altogether explains how the US editors intervene in the adaptation and rewriting of the texts during the editorial process a great deal more than their British peers. The notion of the "editors" as the agents in charge of modifying and adapting books is presented in Chapter 2, and, in order to tackle such power relations, Pillière makes use of the scholarly works of Arrojo (1997), Hermans (1999), and Venuti (1995, 2018).

Another rather noteworthy notion that Pillière takes into consideration in her study is the materiality of the text. Akin to Benjamin (2012) or Venuti (1995, 2018), she highlights the "no referentiality of language," and urges scholars to encompass such materiality when researching intralingual translations. That is why, in Chapter 3, she claims that there exists "different modes in creating textual meaning" (32). Indeed, not only words can create meaning, but visual aspects also included in the material construction of the text can equally influence the readership. Pillière labels the latter as "peritexts" (128), which are usually designed by the publishers and aim to serve a marketable end. With this, Pillière underlines the importance of incorporating a multimodal stylistic perspective when comparing intralingual translations, and how such an approach can help us reflect on the way translation has been defined. 
After outlining the methodology and theories that serve as the basis of her research, in Chapters 4, 5 and 6 the author analyzes the texts, addressing the modifications found in the different geographical versions. Chapter 4 covers the grammatical and lexical differences, whereas Chapter 5 explores changes that are more subtle to the eyes of the reader that could not be considered dialectical, or categorized as "Americanizations," in the author's words. Finally, Chapter 6 shows how said changes alter the "voices within the text" (305), modifying decisive aspects for the reader's interpretation such as the subjectivity of the text and a significant loss of meaning, turning the AmE editions into a more concise, downplayed and Americanized version of the BrE novels.

One of the most compelling ideas that I found in Intralingual Translation of British Novels is the very topical "material" approach to translation. Pillière ponders on the materiality of texts, both originals and translations, by considering "the book in its entirety [in order] to raise awareness of the important role played by the material text" (30). By taking this perspective, she unearths the traces of the editors' intervention in the US editions of novels such as Sarah Ivens's Forest Therapy, Simon Winchester's The Surgeon of Crowthorne, Ian McEwan's Enduring Love, or Joanne Harris's Blackberry Wine, traces that inform on the reception and consumption of these books in the two different countries. All in all, Pillière's book is a ground-breaking and inspiring publication that certainly will benefit imminent dialogues in the field of translation studies, especially any kind of multidisciplinary research that waltzes around the circulation of literature and multimodal stylistic transfers when considering the cultural, sociological, and ideological aspects that intervene in the reception of a text. 